\title{
nature
}

\section{Summer heat fires policy hares}

\section{When the political race to 'cure' the drought problem is over, it will fall to government bureaucrats to sort out a national atmosphere policy}

A Fascinating example of the decision-making process is now playing itself out in Washington, and anyone who has tried to wield a scientific argument in favour of preferred public policy should pay close attention. For it is undoubtedly the case that congressional attitudes about chlorofluorocarbons (CFCs) and carbon dioxide emissions are influenced far more by the fact that the corn in most of Iowa is nowhere near as high as an elephant's eye, and that outside the House and Senate chambers it has been stiflingly hot, than any number of scientific treatises on the subject. And it is equally true that the need to "do something" will be extremely powerful, at least until the rains come and the memory of the hot summer of 1988 has been cooled by the first blizzard of 1989.

When stories about the greenhouse effect appear on covers of national magazines, the topic gets a publicity boost far beyond what any advertising could provide and for a while at least, there is a positive feedback loop, with each segment of the media seeking to outdo others in covering the story. Then came the drought and heat wave, and editors began to ask, quite legitimately, if the drought was related to the greenhouse effect.

Now the true answer is yes, not in the sense that they are causally related, but merely in the sense that conditions on Earth and in the atmosphere must be having some impact on the weather. But understanding that correlation does not necessarily imply causation is an achievement most - including scient ists -- find difficult. The strength of politicians in setting policy lies in their ability to work with uncertain information - the way politicians make decisions needed to run the economy and set public policy would never stand up under strict scientific scrutiny, if decisions could wait until a scientific verdict was in.

Senator Tim Wirth (Democrat, Colorado) has proposed legislation that would limit carbon dioxide emissions, map out an energy strategy for the country, protect tropical rain forests, convene an international conference on greenhouse gases and provide new money for atmosphere research. If the need to "do something" becomes sufficiently great, Congress could do far worse than to adopt Wirth's bill and see where it leads.

But it ultimately falls to the career bureaucrats to implement the law, and as a group they are less influenced by magazine cover stories. The Environmental Protection Agency (EPA) has just announced how it will achieve the reductions in CFC use called for in the yet-to-be ratified Montreal Protocol. EPA will limit the production and consumption of CFC-11, -12, -113, -114 and -115 at 1986 levels, and in mid-1993 bring a 20 per cent reduction in there levels, dropping to 50 per cent of 1986 levels by 1998 . Production quotas will be allocated to five US companies making CFCs based on their historical market share.

EPA has moved according to the letter of the law. But by moving cautiously to implement the Montreal Protocol, it may find that political events will overtake its new rules. This tortoise and hare relationship between politicians and bureaucrats is probably a good thing, in the long run. The bureaucrats act as a kind of buffer in a potentially volatile solution. Even though the EPA may lag in implementing strict CFC emissions, when it starts to rain, and the temperatures cool, it will fall to EPA to maintain momentum for reduced emissions for greenhouse gases. Although maddeningly slow and frustratingly complex, the bureaucratic tortoise will reassuringly plod on while the political hares chase after the next magazine cover.

\section{More missed chances}

\section{President Ronald Reagan leaves tough decisions}

\section{on AIDS to his successors}

SEVEN years into the AIDS epidemic, US President Ronald Reagan appears still not to have resolved his ambivalent attitude towards AIDS, nor to have found any way to balance conservative and liberal opinion other than by inaction. Last week he failed to implement in full the recommendations of his own hand-picked commission on the human immunodeficiency virus (HIV) epidemic. At issue was his apparent unwillingness to give his unqualified backing to the notion that those carrying the virus should be protected from discrimination.

Instead of following the commission's advice and issuing an executive order, which would have mandated federal agencies to adopt rules prohibiting discrimination against AIDS-virus carriers in the workplace, or proposing anti-discrimination legisation that would have had still wider effect, the president opted for a weaker course of action. His ten-point plan directs federal agencies to adopt anti-bias guidelines, worked out by the Office of Personnel Management, and only "requests" that businesses and schools "consider adopting" the guidelines.

The reasoning behind the commission's call for vigorous action to back anti-bias recommendations is simple. While compassion dictates that discrimination should not be added to the burden borne by those who find themselves infected with the AIDS virus, common sense teaches that the AIDS epidemic cannot be countered effectively unless all those who may carry the virus can come forward for diagnosis without fear of penalty. The unwillingness of the administration to get down to the practical reality of dealing with the AIDS epidemic has already been amply demonstrated in its endless commissioning of new reports and years of vacillation over a public campaign. It is no coincidence that the ten-point plan also fails to give the president's backing to the commission's suggestion for a massive increase in expenditure on treatment for intravenous-drug abusers, at the highest risk of contracting AIDS.

With 1.5 million Americans now carrying the AIDS virus, the next president will have little time to put off firmer action. Both candidates have said they will back an anti-discrimination law and pledged support for the presidential AIDS commision's proposals. But whether they will be succesful in the larger task of effective help for drug abusers depends on how effectively they counter the view, which has dominated President Reagan's thinking, that nothing should be done that appears to reward the behaviours that led people to contract AIDS. The new president will have to accept that effective action requires people to be dealt with as they really are, and not as conservative opinion would wish them to be. 